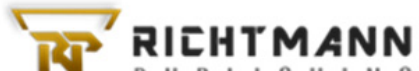

\section{Sharia Economics and Financial Inclusion Program in Indonesia}

\section{Yusup Hidayat}

Universitas Al Azhar, Jakarta, Indonesia

Doi: 10.36941/ajis-2019-0017

\begin{abstract}
This study aims to discuss how Islamic economics through Islamic banking in Indonesia conducts an inclusive financial program through the policies of the Financial Services Authority in Indonesia named Laku Pandai. The method used in this study is qualitative research using normative juridical with the support of primary, secondary, tertiary legal materials and also existing primary data that supports the Laku Pandai policy for Islamic banks. Laku Pandai is a financial inclusion program initiated by the Financial Services Authority. The results of this study indicate that only a limited number of Islamic banks have completed the Laku Pandai program, while most of the others are still in the stage of preparing themselves and have not yet responded to the Laku Pandai program. Many problems issued by sharia banking in implementing the Laku Pandai program are related to infrastructure and resource issues of agents. Two banks of BRI and BTPN in Indonesia are two banks that have implemented the Laku Pandai program while BRI Syariah is ready to do this program.
\end{abstract}

Keywords: Laku Pandai, policy, Islamic banking, agents, implementation

\section{Introduction}

During the global financial crisis of 2007-2009, Islamic finance showed a certain level of resilience to financial shocks (Ibrahim, 2015). This shows that Islamic finance is not only considered as a viable and best alternative, compared to the conventional financial system, but also the most efficient, productive and feasible way of financial intermediation (Ismail et al., 2015; Suadi, 2018). The survival of Islamic finance from the onslaught of the financial crisis is thus proof that Islamic finance deserves a strategic place in contributing to the economic progress of the people, including in Indonesia (Hasan, 2011; Ghofur, \& Susilo, 2017). Both conventional and Islamic banks have a big role in the financial system. The reliability of these two kinds of bank is a major concern regarding financial stability in a country's economic system. While conventional banks carry out intermediary functions, Islamic banks have the unique nature of operations and activities that must conform to sharia principles and decisions (Kuran, 1995). In addition, the main purpose of Islamic banking is to ensure that wealth or money is not concentrated only on the rich, but also among the poor.

In 2012 the government of the Republic of Indonesia launched a National Strategy for Inclusive Finance (SNKI) program. It is expected that from this program the people who have access to financial institutions will increase. Indonesia's Financial Services Authority (Otoritas Jasa Keuangan/OJK) as an institution that functions to regulate, supervise, examine and investigate the program with the issuance of an OJK regulation named POJK No. 19 of 2014 concerning Officeless Financial Services in the Context of Inclusive Finance followed by the issuance of OJK Circular Letter Number 6/SEOJK.03/2015 concerning Officeless Financial Services in the Context of Inclusive Finance by Banks (Hasan, 2012; Lathif \& Habibaty, 2019; Hidayat, 2018). All of the rules 
relating to Laku Pandai issued by OJK are not only intended for conventional banks but also apply to Islamic banking both Sharia Commercial Banks and Sharia People's Financing Banks (BPRS). All Banks can conduct Laku activities after fulfilling the conditions specified by the OJK. This study henceforth aims to discuss how Islamic economics through Islamic banking in Indonesia conducts an inclusive financial program. through the policies of the OJK in Indonesia regarding Laku Pandai carried out by Islamic banking.

\section{Research Methods}

This study uses a qualitative method with a normative juridical approach. Primary, secondary and tertiary legal materials collected are analyzed in depth with the support of primary data from interviews with Islamic banking managers in Indonesia.

\section{Inclusive Finance and Sharia Economy}

In the opening of the 1945 Constitution of Indonesia it was stated that one of the goals of the Indonesian nation is to prosper the life of the nation. Prosperity can be interpreted by various interpretations. For example, from the perspective of Islamic economics, prosperity not only is worldly in dimension but also has a hereafter dimension. Prosperity is not only material but also immaterial, both spiritual and intellectual, and it is the right of every human being, both in the city and in the village, both nobility and ordinary people.

Indonesia as a welfare state requires decision makers in this case the state manager to work hard to realize the ideals of the Indonesian nation. In fact, at present, the control of strategic economic resources in almost all countries in the world, is highly concentrated and owned by a small portion of the population (Pizzigati, 2005; Tsui et al., 2018)). In doing so, the mastery of sources of economic wealth and strategic sectors in Indonesia has been so centralized in the hands of a handful of people who have large capital, both large domestic investors and foreign investors (Leigh \& Van der Eng, 2009). This has led to inequality and economic disparity when one percent of Indonesia's population controls more than half of Indonesia's wealth (Siregar, 2016). It appears that the extraordinary disparity that has had a major impact on the welfare of the Indonesian population (Booth, 2019).

Small, micro, and medium enterprises (MSMEs) which are considered to represent the real people's economy in Indonesia show symptoms that are not performing well compared to large corporate businesses (Siregar, 2006). MSMEs are difficult to develop, especially if they compete with large business actors, and they will even be eroded by the interests of the owners of large capital. In addition, SME-based economies also find it difficult to get access to sufficient formal funding through banking services in running their businesses. Because about $60-80 \%$ of businesses in Indonesia are run on an SME system (Tambunan, 2008), providing adequate funding and financial access for them is considered to be able to broadly increase income and performance of small and medium-sized businesses.

From Islamic perspective, the gap in income and natural resources in the community is contrary to the commitment of Islamic teachings to brotherhood and socio-economic justice. For muslim, these problems should be overcome by the methods taught by Islam. Antonio (2001) stated that some ways offered by Islamic teachings include:

1. Abolition of monopoly, except those carried out by the government for certain fields related to the needs of many people;

2. Guarantee of the involvement of all parties without discrimination to be active in every economic process, both production, circulation and consumption;

3. Guarantee of basic needs fulfillment for every member of the community.

4. Implementation of mandate social economic security insurance (at-takaful al-ijtima'i) where those who have the ability to bear and help the less fortunate.

Since before the global financial crisis in 2008 a discourse on financial inclusion emerged and intensified again after the crisis. In 2010, the G20 confirmed support for financial inclusion programs as a means of reducing world poverty. The Association of South East Asian Nations (ASEAN) has 
also integrated the program in the 2015 Economic Community Blueprint. Similarly, world leaders at the United Nations have included the world's poverty reduction agenda in the eight Millennium Development Goals (MDGs) and in 2015 efforts to reduce poverty were reaffirmed as the first goal of sustainable Development Goals or SDGS (Beik \& Arsyianti, 2016). The results of the "UFA2020 Universal Financial Access by 2020" from World Bank study show that more than half of adults in poor families have never been touched by banking services (Morvant-Roux, 2015). Two billion people are marginalized from formal financial services. Financial inclusion is thus an important world agenda for the creation of a more equitable economic distribution (Levine, 1999).

Until now, there is no standard definition of what is meant by financial inclusion. The Financial Action Task Force (FATF) defined financial inclusion as providing access to adequate range of safe, convenient and affordable financial services and disadvantaged groups, including low income, rural and undocumented persons, who have been underserved or excluded from the formal financial sector. Meanwhile, the Reserve Bank of India defines financial inclusion by the process of ensuring access to appropriate financial products and services groups in particular, and low income groups in particular, and affordable cost in fair and transparent manner by regulated, mainstream institutional players (www.bi.go.id, 2016).

The purpose of financial inclusion is to increase the ability of the community to manage risk and capital so that it can have a greater positive effect. For business groups, financial inclusion is expected to increase the availability of funding and financial access, so that in the end it can productively produce products with added value and improve business performance. For the banking community, this business also needs to involve as many customers as possible who were not previously seen as financially capable by financial institutions. It is expected that after that, they will have more access to formal financial institutions than to informal financial institutions with adequate regulatory schemes (Beik \& Arsyianti, 2016).

Michael Barr (2004), a Professor at Michigan University about Banking The Poor, concluded three things. First, the social benefits of financial inclusion programs far outweigh the costs of doing so. Secondly, technological advancements and low-cost mobile phones have accelerated the success of financial inclusion programs. Thirdly, authority incentives for banking players are needed to create various product and technology innovations to reach those who have been marginalized. Burgess et al. (2005), on Banking for The Poor: Evidence From India, concluded that opening branches of state-owned banks in remote areas increased the number of customers who had not been reached, raised their banking transactions, and succeeded in reducing poverty. in the countryside. Meanwhile Asyraf Wajdi Dasuki (2008) on Banking for The Poor: The Role of Islamic Banking in Microfinance Initiative, concluded that there are still a few Islamic banks that serve the poor in remote areas and suggest group financing to reduce costs in remote areas.

In the Islamic perspective, the sharia financial inclusion can be interpreted as an effort to improve people's accessibility to Islamic financial institutions so that the community is able to manage and distribute financial resources in sharia. Islamic financial inclusion is a means to encourage higher involvement of the entire community towards sharia financial practices (Beik \& Arsyianti, 2016). With the existence of financial inclusion programs, it is an opportunity for Islamic financial institutions to be more actively involved in capturing as many people as possible to use Islamic financial institutions in order to improve their living standards, especially marginalized people. The Financial Services Authority as an institution responsible for regulating, monitoring, checking and investigating took the initiative to encourage financial institutions including sharia financial institutions to conduct financial inclusion programs with the Laku Pandai program. Laku Pandai, an Indonesia abbreviation of Unofficial Financial Services in the Framework of Inclusive Finance, was initiated by Financial Service Authority. The program is contained in POJK No. 19 POJK 32014 issued in 2014 followed by Circular Letter Number 6/SEOJK.03/2015 concerning Services for Inclusive Finance.

\section{Role of Sharia Institutions in Financial Inclusion with Laku Pandai program}

POJK No. 19 of 2014 concerning Financial Inclusion is not specific to conventional banking but also involves Islamic banking. In Article 3 paragraph (2) POJK no. 19 of 2014 stated that Financial 
Service Institutions that can submit applications to become Laku Pandai operators as referred to in paragraph (1) are: (a) Banks, (b) Insurance companies or sharia insurance companies, (c) Financial Service Institutions other than those referred to in letters a and letter b. In Law No. 10 of 1998 stated in Article 1 paragraph (1) it is stated that banks are Business Entities that collect funds from the public in the form of deposits and distribute them to the public in the form of loans and or other forms in order to improve people's lives many. In Article 1 paragraph (3), it is also stated that Commercial Banks are banks that carry out conventional business activities and or based on Sharia Principles which in their activities provide payment traffic services (Lathif \& Habibaty, 2019). Then in Article 12 POJK stated:

The requirements referred to in article 10 paragraph (1) letter b for Rural Banks (BPR) or Sharia Rural Financing Banks (BPRS) are as follows:

a. Have core capital of more than Rp 100,000,000,000.00 (one hundred billion rupiah);

b. Have a health level with a healthy rating during the assessment period in the last 1 (one) year.

c. Have a Non Performing Loan (NPL) or Non Performing Financing (NPF) of no more than $5 \%$ (five percent) during the assessment period in the last 6 (six) months.

d. Have a Minimum Capital Adequacy Ratio (CAR) of at least 12\% (twelve percent).

e. Are not in a state of loss in the last 1 (one) year; and

f. Have no violation of the provisions of certain BPRs or BPRS.

Article 13 also stated that commercial banks based on business activities 1 and BPR or BPRS that have fulfilled the requirements to become an organizing bank as referred to in Article 10 paragraph (1) letter $a$, letter $b$, and letter $c$ may submit applications to conduct internet banking in the order to obtain approval to become a bank of Laku Pandai. The application for conducting internet banking as referred to in paragraph (1) can only be approved if the bank is also approved to become a Bank of Laku Pandai.

Based on the provisions of the above regulations, Islamic banking, both Commercial Banks and Sharia Rural Financing Banks (BPRS), can hold Laku Pandai by fulfilling the requirements regulated by POJK No. 19 of 2014. OJK itself has not issued specific guidelines for implementing Laku Pandai for Islamic banking. The Islamic Bank that first held the Laku Pandai activity was the Bank Rakyat Indonesia Syariah. The four pioneering banks of Laku Pandai organizers are conventional banks, namely PT Bank Rakyat Indonesia Tbk, PT. Bank Mandiri Tbk., PT Bank Tabungan Pensiun Nasional (BTPN), and PT Bank Central Asia Tbk. There is no Islamic banking in it.

Islamic banking conducting Laku Pandai activities began with the inauguration of the BRI Syariah's Laku Pandai in Mataram City, West Nusa Tenggara, which took place at Nurul Hakim Lombok Islamic Boarding School on December 12, 2015. The inauguration was attended by Chairman of the OJK Board of Commissioners, Muliaman D. Hadad. BRIS named the service with the name BRISSmart as an abbreviation of the facility to present the nearest Islamic banks. The purpose of the service from the BRISSmart selling program is not separate from the main objective of the Laku Pandai program, namely to expand access to financial services for people who do not know or use banking services through the convenience of sharia financial services anywhere, without having to be bound by branch offices.

Moch Hadi Santoso as the Director of BRIS stated that there were many conveniences obtained through the Laku Pandai from BRISSmart service, which could open savings at the nearest BRIS's agent with any deposit with the same account number as his cellphone number so that it was easy to remember. Other conveniences are being able to make cash deposit transactions, cash withdrawals, and transfers across friends from BRIS, free monthly savings administration fees, no minimum balance limit, and the BRIS mobile application that makes it easy for customers to check balances and account mutations. The BRIS-Laku Pandai Program has various facilities, especially for people who have not had sufficient access to financial institutions.

For BRIS, this Laku Pandai program is very helpful because the goal is good. This service program without offices can reduce the cost of branching and recruitment of new HR and training. Laku Pandai is a low-cost program. BRIS has a way of implementing this program, namely with mobile banking and training agents who are friends with BRISSmart. Until now BRIS already had 
61 agents who were friends with BRISSmart. So far, those who are agents are still individual, only one agent in the form of a cooperative located in Malang, East Java. There has been no collaboration with other Islamic micro institutions in this program. The Laku Pandai program is a new program, so it needs to work hard to socialize it and need enthusiasm to continue working.

Another state-owned bank, Bank Syariah Mandiri (BSM) is also ery supportive of the Laku Pandai program because people's access to Islamic banking and financial services has become easier. Before implemented the Laku Pandai program, Bank Syariah Mandiri has issued products that can be utilized by the middle to lower segments of society, including Sympathetic Savings and Simple Savings (savings without monthly administration fees), bill payments through Payment Point Online Bank counters, accountless money transfer services through cooperation with post office, as well as micro business financing programs. In the Laku Pandai program of BSM, there are hundreds of outlets that reach remote areas. Besides that, BSM has information technology (internet banking and mobile banking) that allows people to access banking services even though they do not come directly to BSM outlets or branches. Community response to the Laku Pandai BSM program according to BSM is positive. The leadership of BSM strongly supports this program by issuing policies that encourage the development of products that target the lower segments of the community with easy service access (Meidy Ferdiansyah, Senior Human Capital Business partner Manager, BSM, 2016).

The National Pension Savings Bank (BTPN) welcomed the Laku Pandai program which was driven by the OJK. It was considered in line with the company's vision of "Being the Best Islamic Bank, for financial inclusion, changing the lives of millions of Indonesians". BTPN has prepared this Laku Pandai program since 2015. Initially, BTPN is constrained by the licensing issued by the OJK, so that the new BTPN launched the Laku Pandai program on August 1, 2016. All levels of policy makers at BTPN Syariah support this program because it is in accordance with the company's vision. In view of BTPN to carry out the Laku Pandai program, there is no need for cooperation with Islamic micro institutions. BTPN itself does not object to the existing regulations regarding the Laku Pandai program, but the most striking obstacle is the service Level Agreement permit, the lack of clarity time (Kusumawardhani, 2016). Another private bank, Bank Panin Syariah is still in the process of being processed internally to complete the Laku Pandai requirements. Panin Syariah Bank also still complements the technology needed and prepares the operation of branches in the eastern region. Now, this Islamic bank is still preparing to carry out the Laku Pandai program.

Bank Negara Indonesia (BNI) welcomes this Laku Pandai program, with reasons similar to other Islamic banks, namely the public is increasingly easy to access banking. Until now BNI Syariah is still in the licensing process to carry out Laku Pandai activities even though in principle BNI Syariah is ready to implement this program. Sharia Community Financing Bank based on POJK No. 19 of 2014 can take part in the Laku Pandai program yet no one has been involved in the Laku Pandai program. This can happen because the requirements contained in POJK are not easily realized, especially related to infrastructure issues, although in fact sociologically it is more accustomed to communicating with the lower layers of society compared to commercial banks.

\section{Policy Support for the Proliferation of Islamic Microfinance Institutions}

Based on OJK monitoring Islamic banks are still constrained by the infrastructure and technology that need to be prepared in the Laku Pandai program. The policy that encourages cooperation between sharia banking institutions and other sharia financial institutions seems necessary to be realized given the proliferation of Islamic microfinance institutions in Indonesia such as the Baitul Maal wa Tamwil (BMT), another model of microfinance institutions with sharia principles in Indonesia. This can make Islamic financial institutions mutually reinforcing and not play down their respective roles. The Laku Pandai program is expected to synergize between Islamic financial institutions in Indonesia.

The existence of BMT (Baitul Maal wat Tamwil) in Indonesia can be an example of a sharia financial inclusion program. This is due to the progress of BMT in opening access to community groups that have not been served by financial institutions. It is estimated that there are around 20 million people involved in transactions with BMT in all regions of Indonesia (Beik \& Arsyianti, 2016). 
Thus there needs to be a more comprehensive policy made between regulators, considering the existence of BMT is not under the authority of the FSA for now. BMT is a Sharia Financial Services Cooperative (KJKS) which is a savings and loan cooperative that operates with the Islamic sharia system in accordance with Minister of SMEs and Cooperatives Decree No. 91 of 2004 (Cokrohadisumarto, 2018), while the role of BMT has been so great for financial inclusion programs.

Financial inclusion is also expected not to be an arena for the expansion of large entrepreneurs, by drawing as much funding as possible from remote areas and channeled in big cities (Beik \& Arsyianti, 2016). However, it is expected that the funds absorbed in remote areas are used to finance micro-businesses in the area. Moreover, micro-entrepreneurs can also be expected to absorb funds from financial institutions from big cities. Regulators are expected to be sensitive to this problem so that financial inclusion programs can be successful and able to increase the problem of inequality in financial access for the poor.

This study found that Islamic banks that have implemented the Laku Pandai program are BRI Syariah, and BTPN Syariah, while BSM, Bank Panin Syariah. Based on existing data, BSM has launched the Laku Pandai program since the fourth quarter of 2016. Until 2016, there are no BPRS has declared itself ready to do the Laku Pandai program. The results of this study reinforce the results of Ashraf Wajdi's (2008) research that Islamic banking is still minimal in its involvement in financial inclusion programs.

This study also found that there was no synergic policy between sharia financial institutions to support each other in Laku Pandai so that the micro-sharia institutions in the presence of the Laku Pandai program carried out by Islamic banking could be an obstacle to developing further.

\section{Conclusions}

The results of this study reinforce the opinion of Ashraf Wajdi (2008) that Islamic banking has not been much involved in financial inclusion programs. This is not only due to internal factors of Islamic banking institutions related to infrastructure and technology issues but also related to licensing issues from the FSA/OJK. Banks that have carried out Laku Pandai programs are BRI Syariah and BTPN Syariah. The regulations issued by OJK regarding Laku Pandai apply to both conventional and Islamic banking and specific guidelines issued by OJK for Islamic Banking. 3. There are no regulations that synergize between bank institutions and non-banks related to financial inclusion policies, especially for Islamic financial institutions. Considering that BMT as a Non-Bank financial institution has a large role in financial inclusion programs.

Hence, the financial inclusion program is a great national agenda in the welfare of the nation's life, especially for marginalized people, for this reason there is a need for synergies between bank and non-bank financial institutions to make this big agenda successful in regulations that support and strengthen each other. For sharia financial institutions, it is hoped that this financial inclusion financial agenda can create cooperation in a mutual symbiosis between Islamic banking and Islamic microfinance institutions in this case BMT which has been active in financial inclusion programs naturally. As a practical implication, there is a need for regulations that regulate the circulation of funds, where funds absorbed through the Laku Pandai program are oriented towards the development of micro-enterprises as well as increasing the productivity of communities in marginalized areas. Furthermore, funds from urban areas can flow into rural and remote areas. Moreover, there is a need for research related to how the Laku Pandai program is implemented at the level of Laku Pandai agents as well as the destination community of this program, along with perceptions of Islamic microfinance actors.

\section{Reference}

Antonio, M.S. (2015). Islamic banks from theory to practice. Jakarta: Gema Insani.

Barr, M. S. (2004). Banking the poor. Yale J. on Reg, 21, 121.

Beik, I.S., \& Arsyanti, L.D. (2016). Islamic Economics Development. Jakarta: PT RajaGrafindo Persada. 
Booth, A. (2019). Measuring poverty and income distribution in Southeast Asia. Asian-Pacific Economic Literature, 33(1), 3-20.

Burgess, R., Pande, R., \& Wong, G. (2005). Banking for the poor: Evidence from India. Journal of the European Economic Association, 3(2-3), 268-278.

Cokrohadisumarto, W.M. (2016). BMT Practice and Cases. Jakarta: PT RajaGrafindo.

Ghofur, A., \& Susilo, S. (2017). Maslaha as the philosophical, political and legal basis on the Islamic banking legislation in Indonesia. Global Journal Al Thaqafah, 7(1), 7-17.

Hasan, H. (2011). Thought and Development of Sharia Economic Law in the Contemporary Islamic World. Depok: Gramata Publishing.

Hasan, H. (2012). Effective control of financial services authority on sharia banking institutions). Indonesian Legislation Journal 3(3).

Hidayat, Y. (2018). Regulations Related to the Establishment and Development of Sharia Financial Institutions in Indonesia. Journal of Legal, Ethical and Regulatory Issues, 21(4), 1-9.

Ibrahim, M. H. (2015). Issues in Islamic banking and finance: Islamic banks, Shari'ah-compliant investment and sukuk. Pacific-Basin Finance Journal, 34, 185-191.

Ismail, A. G., Ismail, M. A., Shahimi, S., \& Shaikh, S. A. A. (2015, November). Financial inclusiveness in Islamic banking: comparison of ideals and practices based on Maqasid-e-Shari'ah. In 4th International Conference on Inclusive Financial Sector Development (pp. 17-18).

Kuran, T. (1995). Islamic economics and the Islamic subeconomy. Journal of Economic Perspectives, 9(4), 155173.

Lathif, A. A., \& Habibaty, D. M. (2019). The suitability of sharia life insurance policy for pojk no. 69/pojk. 05/2016 and pojk NO. 72/pojk. 05/2016. Jurnal Hukum dan Peradilan, 8(1), 63-83.

Leigh, A., \& Van der Eng, P. (2009). Inequality in Indonesia: What can we learn from top incomes?. Journal of public economics, 93(1-2), 209-212.

Levine, R. (1999). Financial development and economic growth: views and agenda. The World Bank.

Morvant-Roux, S. (2015, May). Social and Solidarity Finance in between the Failure of the Microfinance Paradigm and the Emergence of the Universal Financial Inclusion Paradigm. In UNRISD Workshop 'Social and Solidarity Finance: Tensions, Opportunities and Transformative Potential (pp. 11-12).

Pizzigati, S. (2005). The rich and the rest: The growing concentration of wealth. The Futurist, 39(4), 38

Siregar, D.D. (2016). Redistribution of Assets and Community Economy. Jakarta: Asset Management Synergy.

Suadi, A. (2018). Peluang dan tantangan lembaga keuangan syariah dalam menghadapi era pasar bebas/opportunities and challenges of sharia financial institutions in dealing with free market. Jurnal Hukum dan Peradilan, 7(1), 1-22.

Tambunan, T. (2008). Development of SME in ASEAN with Reference to Indonesia and Thailand. Southeast Asian Journal of Economics, 20(1), 53-83.

Tsui, A. S., Enderle, G., \& Jiang, K. (2018). Income inequality in the United States: Reflections on the role of corporations. Academy of Management Review 43(1).

Wajdi Dusuki, A. (2008). Banking for the poor: the role of Islamic banking in microfinance initiatives. Humanomics, 24(1), 49-66. 